\title{
Biological activity, structural characterization and crystal packing of chromane-carboxylate derivatives
}

\author{
Viktor Vrábel $^{a}$, Július Sivýb, Jan Světlík ${ }^{c}$, \\ Štefan Marchalín ${ }^{\mathrm{d}}$, Šafă̌ Peter $^{\mathrm{d}}$ \\ ${ }^{a}$ Institute of Analytical Chemistry, Faculty of Chemical and Food Technology, Slovak Technical University, \\ Radlinského 9, SK-812 37 Bratislava, Slovak Republic \\ ${ }^{b}$ Institute of Mathematics and Physics, Faculty of Mechanical Engineering, Slovak University of Technology, \\ Námestie slobody 17, SK-812 31 Bratislava, Slovak Republic \\ 'Department of Pharmaceutical Analysis and Nuclear Pharmacy, Faculty of Pharmacy, Comenius University, \\ Odbojárov 10, Bratislava, SK-83232, Slovak Republic \\ ${ }^{d}$ Institute of Organic Chemistry, Catalysis and Petrochemistry, Faculty of Chemical and Food Technology, \\ Slovak Technical University, Radlinského 9, SK-812 37 Bratislava, Slovak Republic \\ viktor.vrabel@stuba.sk
}

\begin{abstract}
We report here the crystal and molecular structure of a new chromane-derivative, namely isopro$\operatorname{pyl}\left(2 \mathrm{R}^{*}, 3 \mathrm{~S}^{*}, 4 \mathrm{~S}^{*}\right)$-4-(benzo[d]thiazol-2-ylamino)-2-hydroxy-2-ethylchromane-3-carboxylate (I), $\mathrm{C}_{21} \mathrm{H}_{22} \mathrm{~N}_{2} \mathrm{O}_{4} \mathrm{~S}$, which crystallizes as racemate in the space group $\mathrm{C} 2 / \mathrm{c}$. Its structure has been solved using X-ray diffraction data obtained at low temperature $(100(2) \mathrm{K})$. In this compound, the chromane moiety consists of a benzene ring fused with a six-membered heterocyclic ring which adopts a distorted half-chair conformation. The molecules are linked by a combination of $\mathrm{O}-\mathrm{H} \cdots \mathrm{N}$ and $\mathrm{N}-\mathrm{H} \cdots \mathrm{O}$ hydrogen bonds, resulting in a twodimensional network which helps stabilizing the crystal structure of the compound (I). Dihedral angle between the chromane and benzothiazol rings is $80.6(1)^{\circ}$.
\end{abstract}

Keywords: carboxylates, crystal structure, chromane, hydrogen bonding

\section{Introduction}

Chromanes (dihydrobenzopyranes) are ubiquitously found in numerous biologically active natural products. Molecules containing a chromane skeleton exhibit a broad range of bioactivities, such as antiviral, antitumor, antimicrobial, sex pheromone, and those of the central nervous system activity (Ellis \& Lockhart, 2007; Horton et al., 2003). Among the rich variety of natural prenylated molecules, chromane derivatives, with an extra dihydropyrano ring, represent a family of compounds endowed with most interesting properties (Nicolaou et al., 2000). All these derivatives are generally characterized by low cellular toxicity and good membrane permeability, properties that make them ideal drug template compounds. Some of these derivatives have been shown to inhibit mycobacterial growth (Prado et al., 2007), as promising therapeutic agents for AIDS (Ma et al., 2008) and possesing antitumoral activity (Tanaka et al., 2004; Zou et al., 2005). Recently, the use of chromane derivatives as therapeutic agents in the treatment of cancer and cell proliferative disorders has also been reported (Kwak et al., 2010; Pecchio et al., 2006). Based on these data, the development of novel chromane-like molecules with potentially high biological activity for the design of new drugs or as molecular building blocks for chemical synthesis is a compelling target for pharmaceutical applications. Chromane carboxylates, especially those with quaternary carbons, with multiple applications have been pursued heavily by the pharmaceutical industry. They were seen as leukotriene D4 (LTD4) inhibitors for the treatment of allergic reactions and inflammatory conditions; as peroxisome proliferator activated receptor (PPAR) agonists for treatment of type 2 diabetes and for their antioxidants/antiarrythmic (Lang et al., 2003) activity.

Chromanones are found to exhibit strong activity in inhibiting in vitro cell growth of human tumor cells (Lampronti et al., 2003). Many chromanone derivatives are versatile intermediates for the synthesis of natural products such as brazillin, hematoxylin, ripariochromene, clausenin, calonlide A and inophylum B (Koojiman et al.,1984; Ellis et al., 1997; Chenera et al., 1993). It has been suggested that they have significant activity against human immunodeficiency virus type I (HIV-1) (Hussain \& Amir, 1986). Chromanone heterocycles have also attracted much attention owing to their important pharmacological properties (Ellis et al., 1977).

Also benzothiazole derivatives possess antitumour properties (Jin et al., 2006; Mortimer et al., 2006; Akhtar et al., 2008). The precise mechanism of 
action for these selectively acting compounds has not yet been identified (O'Brien et al., 2003; Choi et al., 2006). It has been postulated that benzothiazoles are metabolized to as-yet unidentified reactive species, which then form DNA adducts causing cancer cell death. The knowledge of geometric parameters, primary sites available for noncovalent interactions, charge distribution, stereoelectronic properties and conformational flexibility is helpful in the determination of the drug molecular interaction mechanisms.

Based on these facts, we report here the crystal structure of compound (I) (Fig. 1), which crystallizes in the centrosymetric monoclinic space group C2/c as racemic mixtures (RSS, SRR).

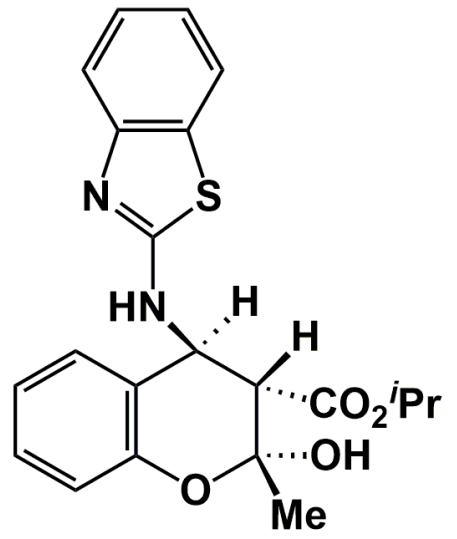

Fig. 1. Molecular structure of compound (I).

\section{Experimental}

Compound (I), isopropyl(2R*,3S*,4S*)-4-(benzo[d] thiazol-2-ylamino)-2-hydroxy-2-ethylchromane-3carboxylate, was prepared according to a standard protocol described in literature (Světlík et al., 2014).

\section{Refinement}

Refinement of $\mathrm{F}^{2}$ against all reflections. The weighted $R$-factor, $w R$, and goodness of fit, $\mathrm{S}$, are based on $\mathrm{F}^{2}$, conventional $R$-factors, $R$, are based on $\mathrm{F}$ with $\mathrm{F}$ set to zero for negative $\mathrm{F}^{2}$. The threshold expression of $\mathrm{F}^{2}>2 \mathrm{~s}\left(\mathrm{~F}^{2}\right)$ is used only to calculate $R$-factors $(\mathrm{gt})$ etc. and is not relevant to the choice of reflections for the refinement. $R$-factors based on $\mathrm{F}^{2}$ are statistically about twice as high as those based on F, and R-factors based on all data are even higher. All $\mathrm{H}$ atoms were positioned with idealized geometry using a constrained riding model with $\mathrm{C}-\mathrm{H}$ distances in the range of $0.95-0.98 \AA$, $\mathrm{N}-\mathrm{H}=0.88 \AA$ and $\mathrm{O}-\mathrm{H}=0.84 \AA$. The $U_{\text {iso }}(\mathrm{H})$ values were set to $1.2 U_{\text {eq }}(\mathrm{C}$-aromatic $)$. Friedel pairs were merged.

\section{Data collection}

Crystal data and conditions of data collection and refinement are reported in Tab. 1. CrysAlis CCD (Oxford Diffraction, 2009); cell refinement: CrysAlis RED (Oxford Diffraction, 2009); data reduction: CrysAlis RED (Oxford Diffraction, 2009); program(s) used to solve structure: SHELXS97 (Sheldrick, 2008); program(s) used to refine structure: SHELXL97 (Sheldrick, 2008); molecular graphics: DIAMOND (Brandenburg, 2001);

Tab. 1. Experimental details.

\begin{tabular}{|c|c|}
\hline Empirical formula & $\mathrm{C}_{21} \mathrm{H}_{22} \mathrm{~N}_{2} \mathrm{O}_{4} \mathrm{~S}$ \\
\hline Formula weight & $\mathrm{M}_{\mathrm{r}}=398.48$ \\
\hline Temperature & $100(2) \mathrm{K}$ \\
\hline Wavelength & $\lambda=0.71073 \AA, \operatorname{MoK}_{\alpha}$ radiation \\
\hline Crystal system, space group & Monoclinic, $C 2 / c$ \\
\hline \multirow[t]{6}{*}{ Unit cell dimensions } & $\mathrm{a}=20.810(1) \AA$ \\
\hline & $\mathrm{b}=9.866(1) \AA$ \\
\hline & $c=20.671(1) \AA$ \\
\hline & $\alpha=90^{\circ}$ \\
\hline & $\beta=108.75(1)^{\circ}$ \\
\hline & $\gamma=90^{\circ}$ \\
\hline Volume & $\mathrm{V}=4018.8(5) \AA^{3}$ \\
\hline Z, Calculated density & $8,1.317 \mathrm{Mg} / \mathrm{m}^{3}$ \\
\hline Crystal size & $0.40 \times 0.20 \times 0.25 \mathrm{~mm}$ \\
\hline \multirow[t]{2}{*}{ Reflections collected/unique } & $80176 / 4104$ \\
\hline & 3767 reflections with $\mathrm{I}>2 \sigma(\mathrm{I})$ \\
\hline Refinement method & Full-matrix least-squares on $\mathrm{F}^{2}$ \\
\hline Data/restraints/parameters & $4104 / 0 / 256$ \\
\hline Goodness-of-fit on $\mathrm{F}^{2}$ & $\mathrm{~S}=1.04$ \\
\hline Final $\mathrm{R}$ indices $[\mathrm{I}>2 \operatorname{sigma}(\mathrm{I})]$ & $\mathrm{R} 1=0.034, \mathrm{w} R 2=0.093$ \\
\hline Largest diff. peak and hole & 0.23 and -0.25 e. $\mathrm{A}^{-3}$ \\
\hline Monochromator & Graphite \\
\hline
\end{tabular}

Tab. 2. Selected geometric parameters: bond lengths $[\AA]$.

\begin{tabular}{llll}
\hline $\mathrm{C} 1-\mathrm{N} 1$ & $1.304(1)$ & $\mathrm{C} 12-\mathrm{C} 16$ & $1.389(2)$ \\
$\mathrm{C} 1-\mathrm{N} 2$ & $1.344(1)$ & $\mathrm{C} 13-\mathrm{O} 2$ & $1.395(2)$ \\
$\mathrm{C} 1-\mathrm{S} 1$ & $1.756(1)$ & $\mathrm{C} 13-\mathrm{O} 1$ & $1.434(2)$ \\
$\mathrm{C} 2-\mathrm{C} 3$ & $1.382(2)$ & $\mathrm{C} 13-\mathrm{C} 17$ & $1.512(2)$ \\
$\mathrm{C} 2-\mathrm{C} 6$ & $1.392(2)$ & $\mathrm{C} 13-\mathrm{C} 14$ & $1.544(2)$ \\
$\mathrm{C} 3-\mathrm{C} 4$ & $1.381(2)$ & $\mathrm{C} 14-\mathrm{C} 18$ & $1.513(2)$ \\
$\mathrm{C} 4-\mathrm{C} 5$ & $1.382(2)$ & $\mathrm{C} 15-\mathrm{C} 16$ & $1.391(2)$ \\
$\mathrm{C} 5-\mathrm{C} 7$ & $1.388(2)$ & $\mathrm{C} 16-\mathrm{O} 1$ & $1.375(2)$ \\
$\mathrm{C} 6-\mathrm{N} 1$ & $1.395(2)$ & $\mathrm{C} 18-\mathrm{O} 4$ & $1.206(2)$ \\
$\mathrm{C} 6-\mathrm{C} 7$ & $1.396(2)$ & $\mathrm{C} 18-\mathrm{O} 3$ & $1.330(2)$ \\
$\mathrm{C} 7-\mathrm{S} 1$ & $1.750(1)$ & $\mathrm{C} 19-\mathrm{O} 3$ & $1.469(2)$ \\
$\mathrm{C} 8-\mathrm{N} 2$ & $1.452(1)$ & $\mathrm{C} 19-\mathrm{C} 20$ & $1.501(3)$ \\
$\mathrm{C} 8-\mathrm{C} 15$ & $1.511(2)$ & $\mathrm{C} 19-\mathrm{C} 21$ & $1.505(3)$ \\
$\mathrm{C} 8-\mathrm{C} 14$ & $1.527(2)$ & $\mathrm{C} 10-\mathrm{C} 11$ & $1.380(3)$ \\
$\mathrm{C} 9-\mathrm{C} 10$ & $1.379(2)$ & $\mathrm{C} 11-\mathrm{C} 12$ & $1.371(3)$ \\
$\mathrm{C} 9-\mathrm{C} 15$ & $1.392(2)$ & $\mathrm{C} 12-\mathrm{C} 16$ & $1.389(2)$ \\
\hline
\end{tabular}


Tab. 3. Selected geometric parameters: bond angles $\left[^{\circ}\right]$.

\begin{tabular}{llll}
\hline $\mathrm{N} 1-\mathrm{C} 1-\mathrm{N} 2$ & $122.4(1)$ & $\mathrm{C} 17-\mathrm{C} 13-\mathrm{C} 14$ & $113.0(1)$ \\
$\mathrm{N} 1-\mathrm{C} 1-\mathrm{S} 1$ & $116.0(1)$ & $\mathrm{C} 18-\mathrm{C} 14-\mathrm{C} 8$ & $109.3(1)$ \\
$\mathrm{N} 2-\mathrm{C} 1-\mathrm{S} 1$ & $121.6(1)$ & $\mathrm{C} 18-\mathrm{C} 14-\mathrm{C} 13$ & $111.0(1)$ \\
$\mathrm{C} 3-\mathrm{C} 2-\mathrm{C} 6$ & $118.8(1)$ & $\mathrm{C} 8-\mathrm{C} 14-\mathrm{C} 13$ & $110.0(1)$ \\
$\mathrm{C} 2-\mathrm{C} 6-\mathrm{N} 1$ & $125.2(1)$ & $\mathrm{O} 1-\mathrm{C} 16-\mathrm{C} 12$ & $116.3(1)$ \\
$\mathrm{C} 2-\mathrm{C} 6-\mathrm{C} 7$ & $119.4(1)$ & $\mathrm{O} 1-\mathrm{C} 16-\mathrm{C} 15$ & $123.1(1)$ \\
$\mathrm{N} 1-\mathrm{C} 6-\mathrm{C} 7$ & $115.4(1)$ & $\mathrm{O} 4-\mathrm{C} 18-\mathrm{O} 3$ & $124.2(1)$ \\
$\mathrm{C} 5-\mathrm{C} 7-\mathrm{S} 1$ & $128.9(1)$ & $\mathrm{O} 4-\mathrm{C} 18-\mathrm{C} 14$ & $123.9(1)$ \\
$\mathrm{C} 6-\mathrm{C} 7-\mathrm{S} 1$ & $109.5(1)$ & $\mathrm{O} 3-\mathrm{C} 18-\mathrm{C} 14$ & $111.8(1)$ \\
$\mathrm{N} 2-\mathrm{C} 8-\mathrm{C} 15$ & $112.0(1)$ & $\mathrm{O} 3-\mathrm{C} 19-\mathrm{C} 20$ & $105.4(2)$ \\
$\mathrm{N} 2-\mathrm{C} 8-\mathrm{C} 14$ & $108.5(1)$ & $\mathrm{O} 3-\mathrm{C} 19-\mathrm{C} 21$ & $108.9(2)$ \\
$\mathrm{O} 2-\mathrm{C} 13-\mathrm{O} 1$ & $108.4(1)$ & $\mathrm{C} 1-\mathrm{N} 1-\mathrm{C} 6$ & $110.5(1)$ \\
$\mathrm{O} 2-\mathrm{C} 13-\mathrm{C} 17$ & $113.3(1)$ & $\mathrm{C} 1-\mathrm{N} 2-\mathrm{C} 8$ & $126.9(1)$ \\
$\mathrm{O} 1-\mathrm{C} 13-\mathrm{C} 17$ & $105.1(1)$ & $\mathrm{C} 16-\mathrm{O} 1-\mathrm{C} 13$ & $117.8(1)$ \\
$\mathrm{O} 2-\mathrm{C} 13-\mathrm{C} 14$ & $108.3(1)$ & $\mathrm{C} 18-\mathrm{O} 3-\mathrm{C} 19$ & $117.2(1)$ \\
$\mathrm{O} 1-\mathrm{C} 13-\mathrm{C} 14$ & $108.5(1)$ & $\mathrm{C} 7-\mathrm{S} 1-\mathrm{C} 1$ & $88.6(1)$ \\
\hline
\end{tabular}

Tab. 4. Hydrogen-bond geometry $(\AA ⿻ \stackrel{\circ}{\circ}$.

\begin{tabular}{lcccc}
\hline$D-\mathrm{H} \cdots A$ & $D-\mathrm{H}$ & $\mathrm{H} \cdots A$ & $D \cdots A$ & $D-\mathrm{H} \cdots A$ \\
\hline $\mathrm{O} 2-\mathrm{H} 2 \mathrm{~W} \cdots \mathrm{N} 1^{\mathrm{i}}$ & 0.84 & 1.97 & $2.777(1)$ & $160(2)$ \\
$\mathrm{N} 2-\mathrm{H} 2 \mathrm{~A} \cdots \mathrm{O} 2^{\mathrm{ii}}$ & 0.88 & 2.54 & $3.157(2)$ & $128(2)$ \\
$\mathrm{N} 2-\mathrm{H} 2 \mathrm{~A} \cdots \mathrm{O} 4^{\mathrm{ii}}$ & 0.88 & 2.20 & $3.008(1)$ & $152(2)$ \\
\hline
\end{tabular}

Symmetry codes: (i) $3 / 2-\mathrm{x} ;-1 / 2+\mathrm{y} ; 3 / 2-\mathrm{z}$; (ii) $3 / 2-\mathrm{x}$; $1 / 2+y ; 3 / 2-z$ software used to prepare material for publication: enCIFer (Allen et al., 2004) and PLATON (Spek, 2009), WinGX (Farrugia, 1999).

\section{Results and Discussion}

Molecular geometry and the atom numbering scheme of the title compound are shown in Fig. 2. Crystal packing of the title compound is shown in Fig. 3. Geometric parameters are provided in Tabs. 2 and 3. The expected stereochemistry of atoms C13, C14, C8 was confirmed as R, S, S.

Conformation of the dihydropyran ring in the chroman moiety is close to that of a distorted halfchair, also called a sofa conformation with the Cremer-Pople puckering amplitude $Q_{\mathrm{T}}=0.501(1) \AA$, $\theta=48.4(2)^{\circ}$ and $\varphi=96.9(2)^{\circ}$ (Cremer, Pople, 1975). Calculation of the least-squares plane shows that thees rings are puckered in such a manner that the five atoms (O1, C13, C8, C15 and C16) of the dihydropyran ring are coplanar, while atom C14 is deviates by 0.656 (2) A from the mean plane. The chromane and benzothiazol fragments are nearly orthogonal to each other, dihedral angle between the least-squares planes of these fragments ring is $80.6(1)^{\circ}$. In compound (I), atom N2 is $s p^{2}$-hybridized, as evidenced by the sum of the valence angles around them $\left(359.9^{\circ}\right)$. These data are consistent with the conjugation of the lone-pair electrons on the nitrogen atom with the adjacent carbonyl, similarly as observed for amides. In the nine-membered benzothiazol ring, non-H atoms do not deviate markedly from coplanarity; the maximum deviation

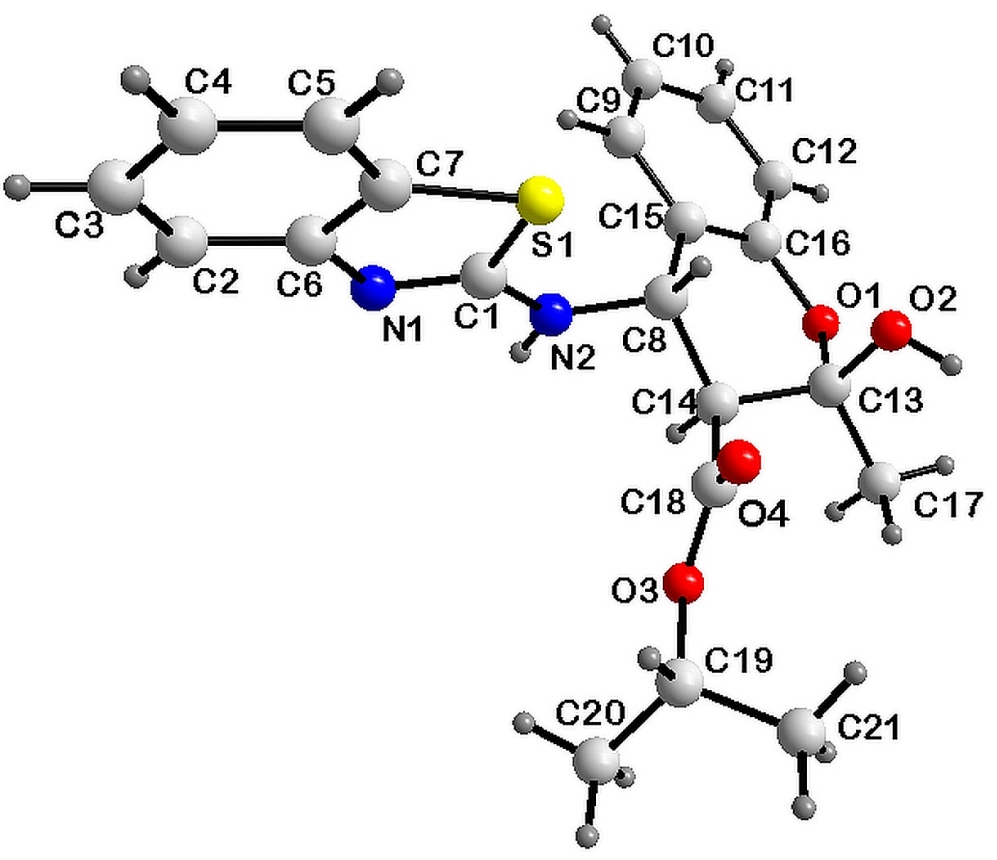

Fig. 2. Molecular structure of compound (I) showing the atom labelling scheme. Displacement ellipsoids are drawn at the $50 \%$ probability level (Brandenburg, 2001). 


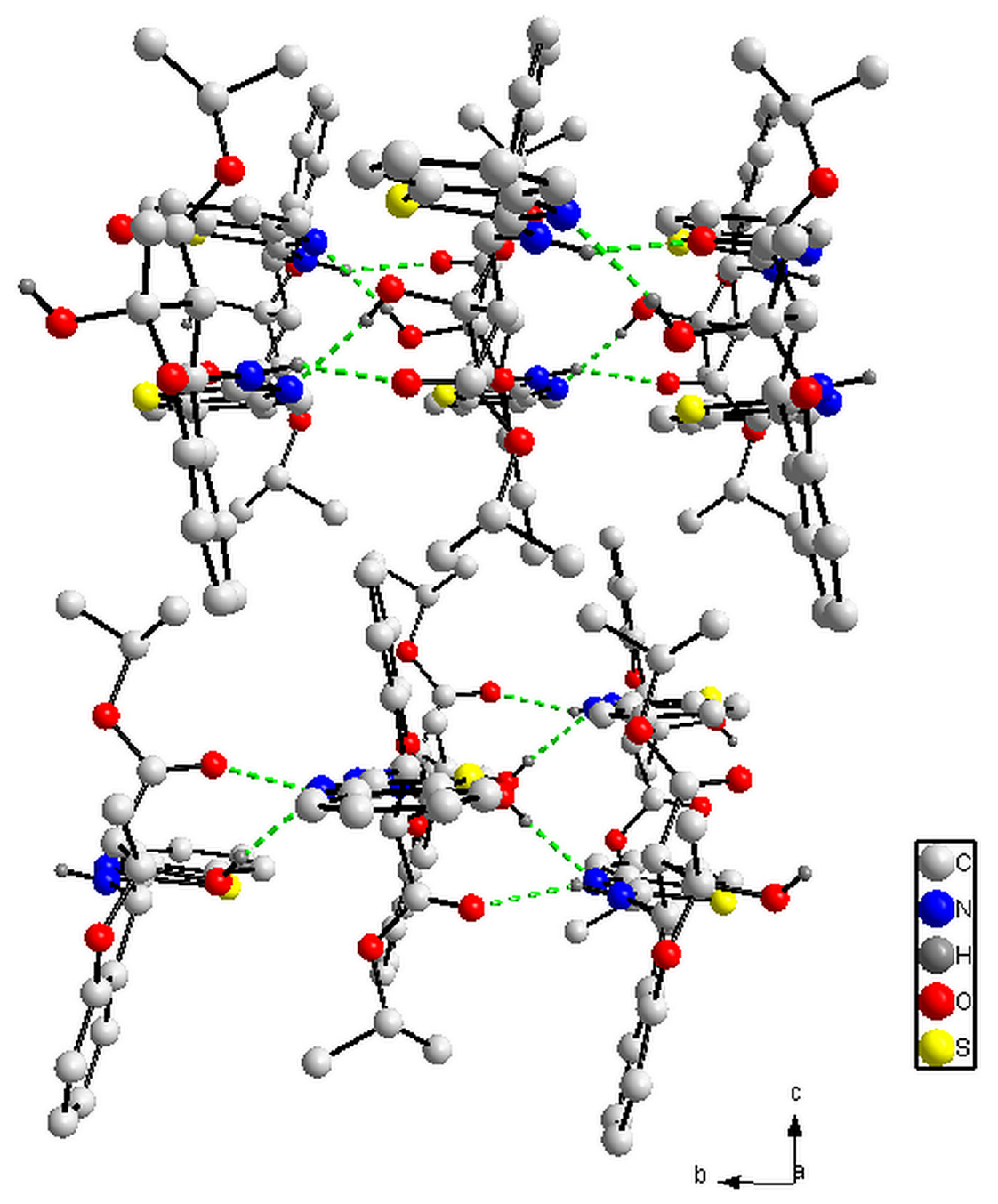

Fig. 3. Part of the crystal structure of (I) showing the formation of hydrogen bond sheets parallel to [010]. Green dashed lines indicate hydrogen bonds. For the sake of clarity, H atoms not involved in the motif shown have been omitted.

from the mean plane of these atoms is exhibited by atom C1 [- 0.026 (2) ^].

There are a number of strong and weak intermolecular hydrogen bonds within the crystal structure of (I); their geometric parameters are given in Table 4. The combination of strong intermolecular $\mathrm{O} 2-$ H2W . . N $1^{\text {i }}$ [symmetry code: (i) $3 / 2-x ;-1 / 2+y$; $3 / 2-\mathrm{z}]$ and N2-H2A . . O $4{ }^{\mathrm{ii}}$ [symmetry code: (ii) $3 / 2-x ; 1 / 2+y ; 3 / 2-z]$ hydrogen bonds link into infinite sheets of molecules along the $b$ axis, and generate the $R_{2}{ }^{2}(10)$ graph-set motif (Bernstein et al., 1995) (Fig. 3).

\section{Acknowledgement}

This work was supported by the Slovak Research and Development Agency (APVV-0797-11) and the Grant Agency of the Slovak Republic (VEGA 1/0873/15, VEGA 1/0371/16 and KEGA, Grant No. 035STU4/2017). This work was also financially supported by the EU structural funds as part of the Security Research
Centre of Excellency ITMS 26240120034, grant from the Research Center for Industrial Synthesis of Drugs, ITMS 26240220061, supported by the Research E Development Operational Programme funded by the ERDF.

\section{References}

Akhtar T, Hameed S, Al-Masoudi NA, Loddo R, La Colla P (2008) Acta Pharm. 58: 135-149.

Allen FH, Johnson O, Shields GP, Smith BR, Towler M (2004) J. Appl. Cryst. 37: 335-338.

Bernstein J, Davis RE, Shimoni L, Chang NL (1995) Angew. Chem. Int. Ed. Engl. 34: 1555-1573.

Brandenburg K (2001) DIAMOND. Crystal Impact GbR, Bonn, Germany.

Cremer D, Pople JA (1975) J. Am. Chem. Soc. 97: 1354-1362.

Ellis GP, Lockhart IM, Meedernycz D, Schweizer EE (1977) Chromenes, Chromanones and Chromones, edited by GP, Ellis. New York: John Wiley and Sons, Inc.

Ellis GP, Lockhart IM (2007). The Chemistry of Heterocyclic Compounds, hromenes, Chromanones and 
Chromones 31: edited by G. P. Ellis 1-119. New York: Wiley-VCH.

Farrugia LJ (1999) J. Appl. Cryst. 30: 565.

Horton DA, Boume GT, Smythe ML (2003) Chem. Rev. 103: 893-930.

Hussain MI, Amir M (1986) J. Indian Chem. Soc. 63: 317-320.

Chenera P, West ML, Finkelstein JA, Dreyer GBJ (1993) J. Org. Chem. 58: 5605-5606.

Choi SJ, Park HJ, Lee SK, Kim SW, Han G, Choo HYP (2006) Bioorg. Med. Chem. 14: 1229-1235.

Jin L, Song B, Zhang G, Xu R, Zhang S, Gao X, Hu D, Yang S (2006) Bioorg. Med. Chem. Lett. 16: 1537-1543.

Koojiman H, Spek AL, Kleijin H, Van Maanen HL, Jastrzelski JT, Van Kozrkowski AP (1984) Acc. Chem. Res. 17: 410-416.

Kwak JH, Kim BH, Jung JK, Kim Y, Cho J, Lee H (2007). Arch. Pharm. Res. 30: 1210-1215.

Lampronti I, Martello D, Bianchi N, Borgatti M, Lambertini E, Piva R, Jabbar S, Shahabuddin Kabir Choudhuri M, Tareq Hassan Khan M, Gambari R (2003) Phytomedicine 10: 300-308.

Lang F, Zewge D, Song ZJ, Biba M, Dormer P, Tschaen D, Volanteb RP, Reiderb PJ (2003) Tetrahedron Lett. 44: 5285-5288.

Ma T, Liu L, Xue H, Li L, Han C, Wang L, Chen Z, Liu G (2008) J. Med. Chem. 51: 1432-1446.
Mortimer CG, Wells G, Crochard JP, Stone EL, Bradshaw TD, Stevens MFG, Westwell AD (2006) J. Med. Chem. 49: 179-185.

Nicolaou KC, Pfefferkorn JA, Roecker AJ, Cao GQ, Barluenga S, Mitchell HJ (2000) J. Am. Chem. Soc. 122: 9939-9953.

O'Brien SE, Browne HL, Bradshaw TD, Westwell AD, Stevens MFG, Laughton CA (2003) Org. Biomol. Chem. 1: 493-497.

Oxford Diffraction (2009). CrysAlisPro. Oxford Diffraction Ltd, Abingdon, Oxfordshire, England.

Pecchio M, Solís PN, López-Pérez JL, Vasquez Y, Rodríguez N, Olmedo D, Correa M, San Feliciano A, Gupta MP (2006) J. Nat. Prod. 69: 410-413.

Prado S, Janin YL, Saint-Joanis B, Brodin P, Michel S, Koch M, Cole ST, Tillequin F, Bost PE (2007) Bioorg. Med. Chem. 15: 2177-2186.

Sheldrick GM (2008) Acta Cryst. A64: 112-122.

Spek AL (2009) Acta Cryst. D65: 148-155.

Svĕtlík J, Prónayová N, Švorc L, Frecer V (2014) Tetrahedron 70: 8354-8360.

Tanaka N, Takaish, Y, Shikishima Y, Nakanishi Y, Bastow K, Lee KH, Honda G, Ito M, Takeda Y, Kodzhimatov OK, Ashurmetov O (2004) J. Nat. Prod. 67: 1870-1875.

Zou YS, Hou AJ, Zhu GF (2005) Chem. Biodivers. 2: 131-138. 